\title{
Систематизація варіантів локалізації і протяжності патологічних венозних рефлюксів у великій підшкірній вені при варикозній хворобі нижніх кінцівок
}

\begin{abstract}
Мета роботи: покращити результати лікування пацієнтів з варикозною хворобою нижніх кінцівок шляхом систематизації всіх варіантів локалізації і протяжності патологічних рефлюксів у стовбурі великої підшкірної вени (ВПВ) для вибору диференційованої хірургічної тактики.

Матеріали і методи. В дослідження включено 560 хворих з варикозною хворобою нижніх кінцівок з патологічними рефлюксами у різних сегментах ВПВ. Всім хворим проводили ультразвукове триплексне сканування венозної системи нижніх кінцівок. Результати досліджень та їх обговорення. Всі можливі варіанти локалізації і протяжності патологічних рефлюксів у стовбурі ВПВ класифіковано на: 1) прості: “тотальний” (неспроможність термінального клапана ВПВ з рефлюксом уздовж усього стовбура аж до рівня кісточок), “проксимальний” (неспроможність термінального клапана ВПВ з рефлюксом у стовбурі до певного рівня, але не до рівня кісточок), “сегментарний” (рефлюкс у будь-якому сегменті ВПВ без ураження проксимальної і дистальної частин вени, тобто без неспроможності термінального клапана та без поширення до рівня кісточок) i “дистальний” (рефлюкс від певного рівня стовбура ВПВ, але не від термінального клапана, до медіальної кісточки); 2) складні: “проксимально-сегментарний”, “проксимально-дистальний”, “сегментарно-дистальний” і “проксимально-сегментарно-дистальний” (комбінації відповідних простих рефлюксів). Різні види рефлюксів зустрічалися з частотами: 33,6 \%, 1,3 \%, 4,8 \%, 35,9 \%, 4,1 \%, 19,1 \%, 0,0 \% та 1,2 \%, відповідно. Розроблено систему інтеграції запропонованої класифікації у міжнародну класифікацію хронічних захворювань вен СЕАР. Перевагами запропонованої класифікації є те, що вона: 1) має чітку практичну спрямованість (для кожного з варіантів рефлюксу - різна лікувальна тактика); 2) враховує всі відомі на сьогодні варіанти поширення рефлюксів; 3) відображає спроможність або неспроможність термінального клапана ВПВ; 4) вказує на наявність чи відсутність кількох окремих сегментів ВПВ з патологічними рефлюксами; 5) враховує поширеність чи непоширеність рефлюксу до рівня кісточок; 6) є лаконічною; 7) може бути інтегрованою в міжнародну класифікацію хронічних захворювань вен СЕАР.
\end{abstract}

Ключові слова: варикозна хвороба нижніх кінцівок; велика підшкірна вена; вертикальні рефлюкси; класифікація.

Постановка проблеми і аналіз останніх досліджень та публікацій. Для відображення наявності рефлюксу у великій підшкірній вені (ВПВ) в міжнародній класифікації хронічних захворювань вен СЕАР передбачено використання двох числових кодів: “2” - для її стегнового сегмента і “3” - для гомілкового. Разом з тим, у цій класифікації немає жодної інформації про ряд, на наш погляд, вкрай важливих характеристик рефлюксу у ВПВ, від яких кардинально залежить тактика лікування: 1) де знаходиться початкова точка рефлюксу; 2) до якого рівня доходить його дистальна межа; 3) яка протяжність рефлюксу; 4) рефлюкс $€$ безперервним чи наявні кілька сегментів вени 3 рефлюксом. Відсутність цієї інформації в класифікації СЕАР не націлює на необхідності диференційованого лікування пацієнтів залежно від варіанту розповсюдження рефлюксів та не дає можливості порівняти результати лікування хворих 3 різними варіантами їх поширення.

У зв’ язку з таким станом справ, дослідниками 3 різних країн запропоновано ряд класифікацій варіантів поширення патологічного венозного рефлюксу, які рекомендується використовувати додатково до СЕАР-класифікації [1, 2, 3, 4, 5, 6] чи інтегрува- ти в цю класифікацію [7]. Разом з тим, не зважаючи на ретельний аналіз всіх подібних класифікацій, ми не знайшли такого їх варіанту, за допомогою якого можна б відобразити всі види локалізації і протяжності рефлюксу у ВПВ, що зустрічаються нами у повсякденній клінічній практиці.

Мета роботи: покращити результати лікування пацієнтів з варикозною хворобою нижніх кінцівок шляхом систематизації всіх варіантів локалізації і протяжності патологічних рефлюксів у стовбурі ВПВ для вибору диференційованої хірургічної тактики.

Матеріали і методи. В дослідження включені 560 хворих з варикозною хворобою нижніх кінцівок з патологічними рефлюксами у будь-якому сегменті ВПВ. Серед обстежених - 403 жінки (72,0 \%) і 157 чоловіків (28,0 \%). Вік хворих коливався від 18 до 83 років. Середній вік хворих склав 49,6 року.

За критерієм С міжнародної класифікації хронічних захворювань вен СЕАР (2004) структура кінцівок була наступною: клас С2 - 75 кінцівок (13,4 \%), C3 - 254 (45,4 \%), C4a - 90 (16,1 \%), C4b - 87 (15,4 \%), C5 - 39 (7,0 \%) та C6 - 15 (2,7\%). 
Всім хворим проводили ультразвукове триплексне сканування венозної системи нижніх кінцівок за допомогою ультразвукових апаратів “LOGIQ e” (GE Healthcare, Великобританія) та “TOSHIBA ffa-580a/ f7” (TOSHIBA, Японія) з використанням лінійних датчиків 3 діапазоном частот 4,0-10,0 МГц та конвексних датчиків $з$ діапазоном частот 2,0-5,5 МГц.

Для статистичної обробки інформації використано редактор “Microsoft Excel 2013” (Microsoft, США), встановлений з підпискою Івано-Франківського національного медичного університету на хмаринку “office 365”.

Результати досліджень та їх обговорення. На основі обстеження хворих, ми синтезували класифікацію варіантів патологічних рефлюксів у стовбурі ВПВ, в якій виділені прості та складні варіанти рефлюксів, причому простих варіантів $є$ лише 4 (табл. 1).

Схематичне зображення видів патологічних рефлюксів у ВПВ представлено на рисунку 1.

Інтегрувати таку класифікацію в класифікацію СЕАР цілком не складно. Для цього ми пропонуємо після кодових чисел ВПВ (“2” і / чи “3”) в дужках вказувати позначку одного з 4 варіантів рефлюксу. I таким чином, виходить, що при інтеграції можливі наступні варіанти записів (табл. 2).

Разом $з$ тим, у стовбурі ВПВ нерідко зустрічається поєднання кількох простих варіантів рефлюксів. Комбінації простих рефлюксів формують наступні варіанти складних рефлюксів: “проксимально-сегментарний”, “проксимально-дистальний”, “сегментарно-дистальний” і “проксимально-сегментарно-дистальний” (рис. 2).

Таблиця 1. Класифрікація простих патологічних рефлюксів у великій підшкірній вені

\begin{tabular}{|c|c|c|}
\hline Вид рефлюксу & Пояснення & Умовне позначення \\
\hline Тотальний & $\begin{array}{l}\text { Неспроможність термінального клапана ВПВ з рефлюксом } \\
\text { уздовж усього стовбура аж до рівня кісточок }\end{array}$ & t (від англ. total) \\
\hline Проксимальний & $\begin{array}{l}\text { Неспроможність термінального клапана ВПВ з рефлюксом } \\
\text { у стовбурі до певного рівня, але не до рівня кісточок }\end{array}$ & р (від англ. proximal) \\
\hline Сегментарний & $\begin{array}{l}\text { Рефлюкс у будь-якому сегменті ВПВ без ураження } \\
\text { проксимальної та дистальної частин вени, тобто без } \\
\text { неспроможності термінального клапана та без поширення } \\
\text { до рівня кісточок. У випадку наявності } 2 \text { таких сегментів з } \\
\text { рефлюксом, відокремлених один від одного сегментом без } \\
\text { рефлюксу, слід вживати термін “двосегментарний”, трьох } \\
\text { - “трисегментарний” і т. д. }\end{array}$ & $\begin{array}{l}\text { “односегментарний” - s } \\
\text { (від англ. segmental), } \\
\text { “двосегментарний”- 2s, } \\
\text { “трисегментарний” - 3s i т. д. }\end{array}$ \\
\hline Дистальний & $\begin{array}{l}\text { Рефлюкс від певного рівня стовбура ВПВ, але не від } \\
\text { термінального клапана, до медіальної кісточки }\end{array}$ & d (від англ. distal) \\
\hline
\end{tabular}
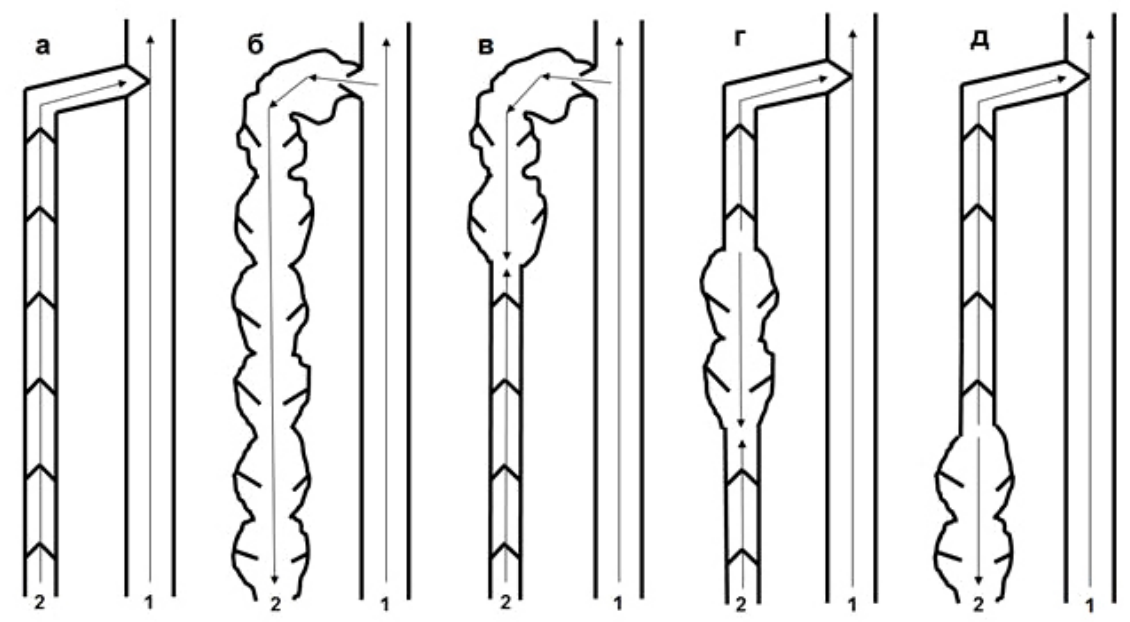

Рис. 1. Класифікація простих патологічних рефлюксів у ВПВ (стрілками зображений напрям руху крові): а) норма; б) тотальний рефлюкс; в) проксимальний рефлюкс; г) сегментарний рефлюкс; д) дистальний рефлюкс. Позначення: 1 - глибока венозна система; 2 - ВПВ. 
Таблиця 2. Інтеграція запропонованої нами класифрікації патологічних рефлюксів у велику порожнинну вену в класифрікацію СЕАР

\begin{tabular}{|c|c|}
\hline Вид рефлюксу & Позначення в класифікації СЕАР \\
\hline Тотальний & $\ldots P_{r \ldots 2,3(t) \ldots}$ \\
\hline Проксимальний & $\begin{array}{l}\ldots \mathrm{P}_{\text {r..2(p)... }}-\text { при дистальній межі рефлюксу вище коліна, } \\
\ldots . . \mathrm{P}_{\text {r..2,3(p)... }}-\text { при дистальній межі рефлюксу нижче коліна }\end{array}$ \\
\hline Сегментарний & $\begin{array}{l}\ldots . \mathrm{P}_{\text {r...2(s)... }}-\text { при дистальній межі рефлюксу вище коліна, } \\
\ldots . \mathrm{P}_{\text {r...(s)... }}-\text { при проксимальній межі рефлюксу нижче коліна, } \\
\ldots . \mathrm{P}_{\text {r...2,3(s)... }} \text { - при проксимальній межі рефлюксу вище коліна, а дистальній межі - нижче } \\
\text { коліна }\end{array}$ \\
\hline Дистальний & $\begin{array}{l}\ldots . P_{\text {r..2,3(d)... при проксимальній межі рефлюксу вище коліна, }} \text { - при проксимальній межі рефлюксу нижче коліна } \\
\ldots . \mathrm{P}_{\text {r...3(d)... }} \text { - при }\end{array}$ \\
\hline
\end{tabular}



Рис. 2. Складні варіанти патологічних рефлюксів у ВПВ (стрілками зображений напрям руху крові): а) проксимально-сегментарний; б) проксимально-дистальний; в) сегментарно-дистальний; г) проксимальносегментарно-дистальний. Позначення: 1 - глибока венозна система; 2 - ВПВ.
Інтеграція складних варіантів рефлюксів у класифікацію СЕАР представлена у таблиці 3.

У всіх випадках, коли зустрічається сегментарний рефлюкс, самостійно або у поєднанні з іншими видами (проксимально-сегментарний, сегментарно-дистальний і проксимально-сегментарно-дистальний), залежно від кількості сегментів вени з цим видом рефлюксу при записі до літери “s” додається цифра, що відповідає кількості таких сегментів, наприклад, “.... $\mathrm{P}_{\mathrm{r} . .2,3(\mathrm{p}-2 \mathrm{2s}) . .}$ ”.

Таким чином, класифікація, яку ми пропонуємо, має лише 4 терміни, при їх комбінаціях може відобразити абсолютно увесь спектр, а точніше, кілька десятків, різних варіантів поширення патологічного рефлюксу у ВПВ, легко інтегруючись в класифікацію СЕАР.

3560 кінцівок з патологічним рефлюксом у тому чи іншому сегменті ВПВ на 526 (93,9 \%) спостерігався сафено-стегновий рефлюкс. 3 цих кінцівок тотальний рефлюкс у ВПВ був зареєстро-

Таблиця 3. Інтеграція складних видів патологічних рефрлюксів у велику порожнинну вену в класифрікацію СЕАР

\begin{tabular}{|c|c|}
\hline Вид рефлюксу & Позначення в класифікації СЕАР \\
\hline Проксимально-сегментарний & $\begin{array}{l}\ldots . \mathrm{P}_{\text {r...2(p-s)... }} \text { - при розміщенні дистальної межі сегментарного рефлюксу вище } \\
\text { коліна, } \\
\ldots \mathrm{P}_{\text {r...2,3(p-s)... }}-\text { при дистальній межі сегментарного рефлюксу нижче коліна }\end{array}$ \\
\hline Проксимально-дистальний & $\ldots \mathrm{P}_{\mathrm{r} \ldots 2,3(\mathrm{p}-\mathrm{d}) \ldots}$ \\
\hline Сегментарно-дистальний & $\begin{array}{l}\ldots . P_{\text {r...2,3(s-d)... }} \text { при розміщенні проксимальної межі сегментарного рефлюксу } \\
\text { вище коліна, } \\
\ldots . P_{\text {r...3(s-d).... при розміщенні проксимальної межі сегментарного рефлюксу }} \\
\text { нижче коліна }\end{array}$ \\
\hline $\begin{array}{l}\text { Проксимально-сегментарно- } \\
\text { дистальний }\end{array}$ & $\ldots P_{r \ldots 2,3(p-s-d) \ldots}$ \\
\hline
\end{tabular}


ваний на 201 (35,9 \% 3 усіх кінцівок та 38,2 \% 3 кінцівок із сафено-стегновим рефлюксом), проксимальний - на 188 (відповідно, 33,6 та 35,7 \%), проксимально-дистальний - на 107 (відповідно, $19,1 \%$ та 20,3 \%), проксимально-сегментарний - на 20 (відповідно, 3,6 \% та 3,8 \%), проксимально-сегментарно-дистальний - на 7 (відповідно, $1,25 \%$ та 1,33 \%) та проксимально-двосегментарний - на 3 (відповідно, 0,54 \% та 0,57 \%).

Відсутнім сафено-стегновий рефлюкс був на 34 кінцівках (6,1 \%). На 7 з них спостерігався сегментарний рефлюкс (1,3 \% з усіх кінцівок та 20,6 \% 3 кінцівок без сафено-стегнового рефлюксу), а на решті 27 (відповідно, 4,8 \% та 79,4 \%) - дистальний.

При обговоренні результатів, які ми отримали, насамперед, проаналізуємо вже відомі класифікації локалізації і протяжності патологічних рефлюксів у ВПВ.

Однією з перших і добре відомих класифікацій протяжності рефлюксу у стовбурі ВПВ є класифікація Насh (1979) [1]. Згідно з цією класифікацією, розрізняють 4 ступені протяжності рефлюксу у ВПВ (Hасh I - наявність лише у ділянці паху, Hach II - закінчення вище коліна, Насh III - закінчення між коліном та медіальною кісточкою, Hach IV - вздовж усієї вени). Ця класифікація відображає дистальний рівень поширення рефлюксу та його загальну протяжність, але, як і класифікація СЕАР, не враховує імовірність локалізації проксимальної межі рефлюксу у будь-якій іншій, крім гирла ВПВ, точці, а також можливості наявності кількох ділянок стовбура ВПВ з рефлюксами.

Схожу класифікацію знаходимо і у Шевченко Ю. Л. та співавт., які поділяють рефлюкс у ВПВ залежно від локалізації і протяжності на локальний (аналог Насh I), розповсюджений (від паху до колінного суглоба), субтотальний (від паху до нижньої третини гомілки) та тотальний (аналог Насh IV) [2]. Однак, крім цих чотирьох варіантів, автори виділяють також сегментарний рефлюкс (у будьякому центральному сегменті стовбура вени). Отже, у цій класифікації враховується імовірність локалізації проксимальної межі рефлюксу не лише в гирлі ВПВ, але теж не передбачається можливості наявності кількох ділянок ВПВ з рефлюксами.

Інші класифікації прагнуть об'єднати в собі не лише варіанти поширення рефлюксу у ВПВ, але й його взаємозв'язок з рефлюксом у інших поверхневих венах. Однією з таких класифікацій є класифікація P. Pittaluga [3]. Згідно з цією класифікацією, розрізняють 5 типів венозного рефлюксу: 1) тип 1 - наявність варикозно розширених немагістральних поверхневих вен на стегні і/або гомілці при спроможному ССЗ і відсутності рефлюксу у стовбурі ВПВ; 2) тип 2 - рефлюкс у ВПВ без варикозного розширення ï̈ гілок: підтип 2a - СС3 спроможне, рефлюкс не досягає рівня кісточок; підтип 2b - ССЗ спроможне, рефлюкс досягає рівня кісточок; підтип 2с - СС3 неспроможне, рефлюкс не досягає рівня кісточок; підтип 2d - СС3 неспроможне, рефлюкс досягає рівня кісточок; 3) тип 3 - варикозне розширення немагістральних поверхневих вен з рефлюксом у ВПВ, але спроможним ССЗ: підтип За - рефлюкс не досягає рівня кісточок; підтип $3 \mathrm{~b}$ - рефлюкс досягає рівня кісточок; 4) тип 4 - варикозне розширення немагістральних поверхневих вен з рефлюксом у ВПВ і неспроможним СС3: підтип 4a - рефлюкс не досягає рівня кісточок; підтип 4b - рефлюкс досягає рівня кісточок; 5) тип 5 - ССЗ неспроможне 3 рефлюксом у гілки, стовбур ВПВ - без рефлюксу.

У зв'язку з тим, що ця класифікація менш точно, ніж класифікація Hach, вказує на дистальну межу рефлюксу, а єдиною відмінністю між підтипами 2а$\mathrm{d}$ та 3a-4b $\epsilon$ наявність рефлюксу у немагістральних поверхневих венах, то Д. А. Касьян і співавт. рекомендують спростити цю класифікацію і об’єднати з класифікацією Насh [7]. В результаті пропонуються 4 варіанти рефлюксу у поверхневих венах: А - відповідає I типу рефлюксу в класифікації P. Pittaluga, В - вертикальний рефлюкс у ВПВ зі спроможним ССЗ, С - вертикальний рефлюкс у ВПВ з неспроможним CC3, D - відповідає 5-му типу рефлюксу в класифікації P. Pittaluga. Для опису протяжності вертикального рефлюксу до буквенного позначення додається римська цифра, що відповідає ступеням класифікації Насh. Автори рекомендують інтегрувати цю класифікацію в анатомічну частину класифікації СЕАР, наприклад “А фікації варіантів поширення венозних рефлюксів у класифікацію СЕАР, на наш погляд, $є$ найбільш вірною. Однак у представленій класифікації, як і у попередніх, все ж не передбачено можливості наявності кількох ділянок стовбура ВПВ з рефлюксами.

Інша класифікація, яка об’єднує в собі варіанти поширення рефлюксу як у ВПВ, так і у немагістральних поверхневих венах, представлена Т. В. Алекперовою та співавт. [4]. Порівняно з усіма вищевказаними класифікаціями, вона найповніше представляє варіанти поширення патологічних рефлюксів у поверхневих венах, а також передбачає можливість наявності рефлюксу у кількох відокремлених один від одного сегментах ВПВ. Разом 3 тим, класифікація громіздка (лише для ВПВ передбачає 16 варіантів поширення рефлюксу), i, не зважаючи на це, не всі відомі варіанти поширення рефлюксу можна віднести до одного з виділених у ній типів. Зокрема, не передбачений у класифікації варіант, коли рефлюкс наявний уздовж усієї ВПВ, крім якогось серединного сегмента.

Ще в одній класифікації, представленій C. A. Engelhorn і співавт. (2005), рефлюкси у ВПВ 
поділяються на 6 типів: I - пригирловий, що поширюється з гілок ССЗ на стовбур ВПВ; ІІ - проксимальний - з ССЗ до гілки або пронизної вени вище рівня кісточок; III - дистальний - від гілки або пронизної вени по ВПВ до кісточок; IV - сегментарний - від гілки або пронизної вени по ВПВ до іншої гілки або пронизної вени вище кісточок; V багатосегментарний - якщо є два або більше різних сегментів із зворотним кровотоком; VI - поширений - вздовж усієї ВПВ від ССЗ до кісточок. На наш погляд, дуже цінним в класифікації є те, що в ній поєднуються 2 важливі моменти: 1) відношення рефлюксу до ССЗ і до кісточок; 2) врахування можливості сегментарного та багатосегментарного поширення рефлюксу у ВПВ. Разом $з$ тим, пригирловий рефлюкс у цій класифікації дублює сегментарний або дистальний рефлюкси, а для багатосегментарного рефлюксу не передбачено зв'язку з ССЗ та поширення чи непоширення його до кісточок, що не дає можливості передбачити необхідний об’єм втручання на венах. У 2014 році автори модифікували класифікацію. В новій класифікації пригирловий рефлюкс не виділяється окремо, а багатосегментарний рефлюкс поділяється на такий, що має зв'язок із ССЗ, і такий, що не має з ним зв'язку [8]. Разом з тим, так і залишається не передбаченим поширення чи непоширення багатосегментарного рефлюксу до рівня кісточок.

Підсумовуючи все вищесказане, зазначимо, що в доступних літературних джерелах ми не виявили жодної класифікації, якою можна було б охарактеризувати всі відомі варіанти поширення рефлюксу у стовбурі ВПВ. Відсутність такої класифікації не дозволяє облікувати, науково опрацьовувати та порівнювати результати диференційованого лікування осіб з різними варіантами поширення рефлюксів. Крім того, без наявності такої класифікації майже неможливо дотриматися одного з основних принципів хірургічного лікування пацієнтів з ВX - "незмінені сегменти ВПВ доцільно зберігати”. Вважаємо, що потреба в такій класифікації вкрай назріла.

Класифікація, яку ми розробили: 1) має чітку практичну спрямованість (для кожного з варіантів рефлюксу - різна лікувальна тактика); 2) враховує всі відомі на сьогодні варіанти поширення рефлюксів; 3) відображає спроможність або неспроможність термінального клапана ВПВ; 4) вказує на наявність чи відсутність кількох окремих сегментів ВПВ з патологічними рефлюксами; 5) враховує поширеність чи непоширеність рефлюксу до рівня кісточок; 6) є лаконічною; 7) може бути інтегрованою в міжнародну класифікацію хронічних захворювань вен СЕАР.

Деталізуючи практичну спрямованість класифікації, зауважимо, що наші рекомендації щодо хірургічної тактики при кожному з видів рефлюксів у ВПВ $є$ наступними: при тотальному рефлюксі - висока перев'язка і пересічення ВПВ $з$ подальшим видаленням усього стовбура ураженої вени (рис. 3, а); при проксимальному - висока
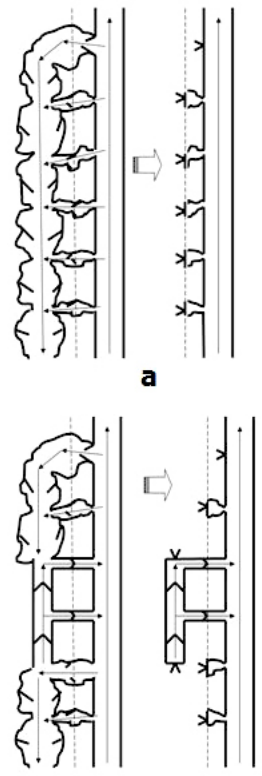

A
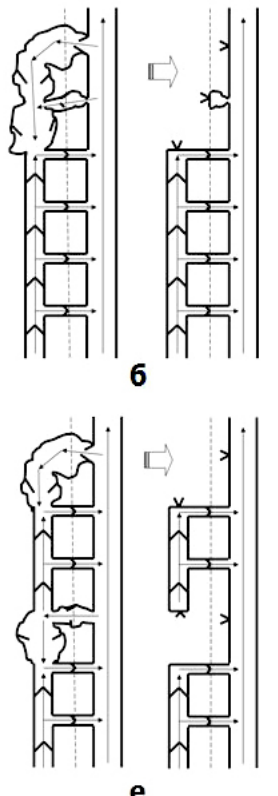
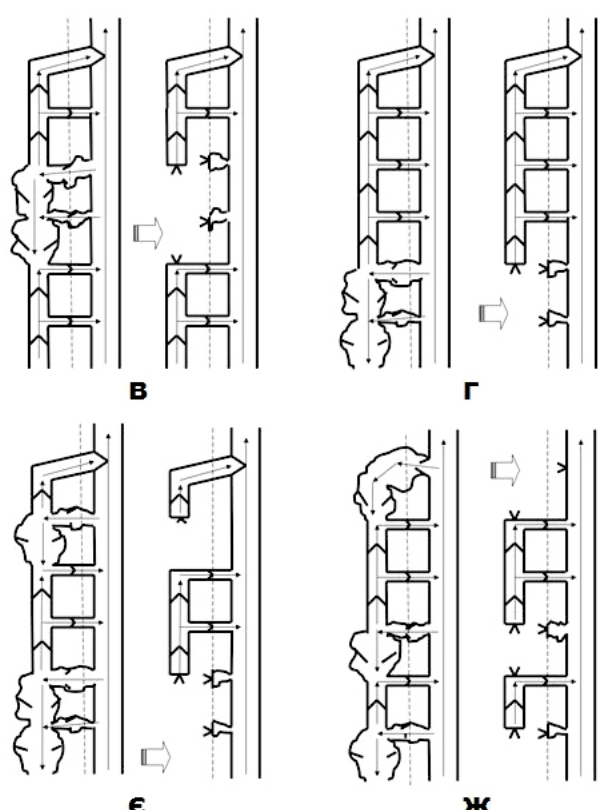

Рис. 3. Диференційована хірургічна тактика при різних варіантах локалізації і протяжності патологічних рефлюксів у ВПВ: а) при тотальному рефлюксі; б) при проксимальному; в) при сегментарному; г) при дистальному; д) при проксимально-дистальному; е) при проксимально-сегментарному; є) при сегментарно-дистальному; ж) при проксимально-сегментарно-дистальному. 
перев'язка і пересічення ВПВ з видаленням проксимальної частини стовбура до дистального рівня поширення рефлюксу (рис. 3, б); при сегментарному - видалення серединного сегмента ВПВ з рефлюксом з залишенням проксимальної та дистальної частин вени (рис. 3, в); при дистальному - видалення дистального сегмента ВПВ з рефлюксом з залишенням неураженої проксимальної частини вени (рис. 3 , г); при проксимально-дистальному - висока перев'язка і пересічення ВПВ з видаленням уражених проксимальної і дистальної частин вени та залишенням неураженого серединного сегмента (рис. 3, д); при проксимальносегментарному - висока перев'язка і пересічення ВПВ з видаленням проксимального і ураженого серединного сегмента вени та залишенням дистального і неураженого серединного іï сегмента (рис. 3, е); при сегментарно-дистальному - видалення дистального та ураженого серединного сегментів ВПВ з залишенням проксимального і неураженого серединного ї̈ сегментів (рис. 3, є); при проксимально-сегментарно-дистальному - висока перев'язка ВПВ з видаленням уражених проксимальної, серединної і дистальної частин вени та залишенням двох неуражених серединних сегментів (рис. 3, ж).

\section{СПИСОК ЛІТЕРАТУРИ}

1. Bergan, J. J. The vein book. / J. J. Bergan, N. Bunke-Paquette. - 1 edition. - Waltham: Academic Press, 2006. -640 p. - ISBN 978-012-369-515-4.

2. Шевченко Ю. Л. Основы клинической флебологии / Под ред. Ю. Л. Шевченко, Ю. М. Стойко, М. И. Лыткина. - М. : ОАО “Издательство “Медицина”, 2005. - 312 с. - ISBN 9785-91976-090-0.

3. Pittaluga P. Classification of saphenous refluxes: implications for treatment / P. Pittaluga, S. Chastane, B. Rea [et al.] // Phlebology. - 2008. - Vol. 23, No. 1. - P. 2-9.

4. Алекперова Т. В. Амбулаторная флебологическая практика: диагностические новации / Т. В. Алекперова, С. Б. Ткаченко, Н. Ф. Берестень [и др.] // Амбулаторная хирургия. 2005. - № 4. - C. 5-15.

5. Чернуха Л. М. Проблема варикозной болезни нижних конечностей сегодня. Наиболее дискуссионные вопросы /

\section{REFERENCES}

1. Bergan, J.J. (2006). The vein book. Waltham: Academic Press. 2. Shevchenko, Yu.L., Stoyko, Yu.M., \& Lytkina, M.I. (Eds.). (2005). Osnovy klinicheskoy flebologii [Basics of clinical phlebology]. Moscow: Medicine [in Russian].

3. Pittaluga, P., Chastanet, S., Rea, B., \& Barbe, R. (2008). Classification of saphenous refluxes: implications for treatment. Phlebology, 23 (1), 2-9.

4. Alekperova, T.V. Tkachenko, S.B. \& Beresten N.F. (2005). Ambulatornaya flebologicheskaya praktika: diagnosticheskie novatsii [Outpatient phlebology practice: diagnostic innovations].
Враховуючи все вищевказане, рекомендуємо розроблену нами класифікацію для широкого клінічного використання.

Висновки. 1. Всі можливі варіанти локалізації і протяжності патологічних рефлюксів у стовбурі ВПВ при варикозній хворобі запропоновано поділяти на прості (проксимальний, сегментарний, дистальний і тотальний) та складні (проксимально-сегментарний, проксимально-дистальний, сегментарно-дистальний та проксимально-сегментарно-дистальний) з застосуванням при кожному з них специфічної хірургічної тактики.

2. Серед обстежених пацієнтів частота вищевказаних рефлюксів склала 33,6 \%, 1,3 \%, 4,8 \%, $35,9 \%, 4,1 \%, 19,1 \%, 0,0 \%$ та $1,2 \%$.

3. Розроблена проста система інтеграція запропонованої класифікації локалізації і протяжності патологічних рефлюксів у стовбурі ВПВ у міжнародну класифікацію хронічних захворювань вен СЕАР.

Перспективи подальших досліджень передбачають вивчення можливості використання розробленої нами класифікації для МПВ з її інтеграцією в міжнародну класифікацію хронічних захворювань вен СЕАР.

Л. М. Чернуха, А. А. Гуч, А.О. Боброва // Хірургія України. - 2010. - № 1. - С. 42-49.

6. Константинова Г. Д. Вертикальный рефлюкс при варикозной болезни нижних конечностей: варианты, диагностика, лечение / Г. Д. Константинова // Ангиология и сосудистая хирургия. - 2009. - Т. 15, № 4. - С. 55 - 59.

7. Касьян Д. А. Варианты патологического венозного рефлюкса при варикозной болезни и выбор метода хирургического лечения / Д. А. Касьян, Е. В. Гуцу, В. С. Кулюк // Матеріали IV з'їзду судинних хірургів і ангіологів України за міжнародною участю 12-14 вересня 2012 р. - 2012. - С. 96 - 101. 8. Associations of anterior accessory or thigh posterior tributary and great saphenous reflux patterns in early stages of chronic venous valvular insufficiency / C. A. Engelhorn, A. L. Engelhorn, S. X. Salles-Cunha [et al.] // Veins and Lymphatics. - 2014. Vol. 3. - P. 23-28.

Ambulatornaya khirurgiya - Outpatient Surgery, 4, 5-15 [in Russian].

5. Chernukha, L.M., Huch, A.A., \& Bobrova, A.O. (2010). Problema varykoznoy bolezni nizhnikh konechnostey sehodnya. Naybolee diskussionnye voprosy [The problem of varicose veins of the lower extremities today. Most controversial issues]. Khirurhiia Ukrainy - Surgery of Ukraine, 1, $42-49$ [in Russian]. 6. Konstantynova, G.D. (2009). Vertikalnyy reflyuks pri varykoznoy bolezni nizhnikh konechnostey: varianty, diagnostika, lechenie [Vertical reflux for varicose veins of lower extremities: 
types, diagnosis, treatment]. Angiolohiya i sosudistaya khirurgiya - Angiology and Vascular Surgery, 15 (4), 55-59 [in Russian]. 7. Kasyan, D.A., Gutsu, E.V., \& Kulyuk, V. S. (2012). Varianty patologicheskogo venoznogo reflyuksa pri varykoznoy bolezni i vybor metoda khirurhicheskogo lecheniya [Options for pathological venous reflux in varicose veins and the choice of surgical treatment]. Abstracts of the 4th International Congress

of Vascular Surgeons and Angiologists of Ukraine. Uzhhorod, September 12-14 [in Russian].

8. Engelhorn, C.A., Engelhorn, A.L., Salles-Cunha, S.X., Andreatta, C.B., Santos, D.B., Nakata, G.T., \& Haida, F.A. (2014). Associations of anterior accessory or thigh posterior tributary and great saphenous reflux patterns in early stages of chronic venous valvular insufficiency. Veins and Lymphatics, 3 (1).

Отримано 02.12.2019

Електронна адреса для листування: r.sabadosh@gmail.com

\title{
R. V. SABADOSH
}

Ivano-Frankivsk National Medical University

\section{SYSTEMATIZATION OF LOCALIZATION AND EXTENSION OF PATHOLOGICAL VENOUS REFLUXES IN GREAT SAPHENOUS VEIN AT PRIMARY VARICOSE VEINS OF THE LOWER LIMBS}

\begin{abstract}
The aim of the work: to improve the results of treatment of patients with primary varicose veins of the lower limbs by systematizing all types of localization and extention of pathological refluxes in the trunk of a great saphenous vein (GSV) for choosing differentiated surgical tactics.

Materials and Methods. The study included 560 patients with primary varicose veins of the lower limbs with pathological refluxes in different segments of GSV. All patients underwent ultrasound triplex scan of the venous system of the lower limbs.

Results and Discussion. All the possible types of localization and extention of pathological refluxes in the GSV trunk are classified into: 1) simple: "total" (incompetence of the terminal valve of the GSV with reflux along all the trunk up to the malleoli level), "proximal" (incompetence of the terminal valve of the GSV with reflux in the trunk to a certain level, but not to the malleoli), "segmental" (reflux in any segment of the GSV without involvement the proximal and distal parts of the vein, that is without terminal valve incompetence and without spreading to the malleoli level) and "distal" (reflux from a certain level of the GSV trunk, but not from the terminal valve, to the malleoli level); 2) complex: "proximal-segmental", "proximal-distal", "segmental-distal" and "proximal-segmental-distal" (combinations of corresponding simple refluxes). All these types of refluxes were observed with the following frequencies: $33.6 \%$, $1.3 \%, 4.8 \%, 35.9 \%, 4.1 \%, 19.1 \%, 0.0 \%$ and $1.2 \%$, respectively. A system of integration of the proposed classification into the international classification of chronic vein diseases CEAP has been developed. The advantages of the proposed classification are: 1) it has a clear practical orientation (for each of the reflux types different therapeutic tactics must be applied); 2) it takes into account all known nowadays types of the reflux spread; 3 ) it reflects the competence or incompetence of the terminal valve of the GSV; 4) it indicates the presence or absence of several separate segments of GSV with pathological refluxes; 5) it takes into account the spread or non-spread of reflux to malleoli level; 6) it is laconic; 7) it can be integrated into the international classification of chronic vein diseases CEAP.
\end{abstract}

Key words: varicose veins disease of the lower limbs; great saphenous vein; vertical refluxes; classification.

\section{Р. В. САБАДОШ}

Івано-Франковский национальный медицинский университет

\section{СИСТЕМАТИЗАЦИЯ ВАРИАНТОВ ЛОКАЛИЗАЦИИ И ПРОТЯЖЕННОСТИ ПАТОЛОГИЧЕСКИХ ВЕНОЗНЫХ РЕФЛЮКСОВ В БОЛЫШОЙ ПОДКОЖНОЙ ВЕНЕ ПРИ ВАРИКОЗНОЙ БОЛЕЗНИ НИЖНИХ КОНЕЧНОСТЕЙ}

\footnotetext{
Цель работы: улучшить результаты лечения пациентов с варикозной болезнью нижних конечностей путем систематизации всех вариантов локализации и протяженности патологических рефлюксов в стволе большой подкожной вены (БПВ) для выбора дифференцированной хирургической тактики.

Материалы и методы. В исследование включены 560 больных с варикозной болезнью нижних конечностей с патологическими рефлюксами в различных сегментах БПВ. Всем больным проводили ультразвуковое триплексное сканирование венозной системы нижних конечностей.

Результаты исследований и их обсуждение. Все возможные варианты локализации и протяженности патологических рефлюксов в стволе БПВ классифицированы на: 1) простые: “тотальный” (несостоятельность терминального клапана БПВ с рефлюксом вдоль всего ствола до уровня лодыжек), “проксимальный” (несостоятельность терминального клапана БПВ с рефлюксом в стволе до определенного уровня, но не до уровня лодыжек), “сегментарный” (рефлюкс в любом сегменте БПВ без поражения проксимальной и дистальной частей вены, то есть без несостоятельности терминального клапана и без распростра-
} 


\section{З ДОСВІДУ РОБОТИ}

нения до уровня лодыжек) и “дистальный” (рефлюкс от определенного уровня ствола БПВ, но не от терминального клапана, до медиальной лодыжки); 2) сложные: “проксимально-сегментарный”, “проксимально-дистальный”, “сегментарно-дистальный” и “проксимально-сегментарно-дистальный” (комбинации соответствующих простых рефлюкс). Различные виды рефлюксов встречались с частотами: 33,6 \%, 1,3 \%, 4,8 \%, 35,9 \%, 4,1 \%, 19,1 \%, 0,0 \% и 1,2 \%, соответственно. Разработана система интеграции предложенной классификации в международную классификацию хронических заболеваний вен СЕАР. Преимуществами предложенной классификации является то, что она: 1) имеет четкую практическую направленность (для каждого из вариантов рефлюкса - разная лечебная тактика); 2) учитывает все известные на сегодняшний день варианты распространения рефлюксов; 3) отражает состоятельность или несостоятельность терминального клапана БПВ; 4) указывает на наличие или отсутствие нескольких отдельных сегментов БПВ с патологическими рефлюксами; 5) учитывает распространенность или нераспространенность рефлюкса до уровня лодыжек; 6) является лаконичной; 7) может быть интегрированной в международную классификацию хронических заболеваний вен СЕАР.

Ключевые слова: варикозная болезнь нижних конечностей; большая подкожная вена; вертикальные рефлюксы; классификация. 